Vol. I. No 22016

\title{
DEATH IN METAPHORICAL LANGUAGE
}

\author{
Agnieszka Uberman
}

Uberman, A. Death in metaphorical language // Lege artis. Language yesterday, today, tomorrow. The Journal of University of SS Cyril and Methodius in Trnava. Warsaw: De Gruyter Open, 2016, vol. I (2), December 2016. p. 171-211. DOI: 10.1515/lart-2016-0013 ISSN 2453-8035

\begin{abstract}
The article presents the analysis of the lexical phrases employing the selected elements of the cognitive frame of DEATH. A brief outline of the symbolism of death is also noted. The corpus for the present analysis has been collected from a number of lexicographic sources. The research results point to the negative meaning of most phrases where death, dead or to die are employed.
\end{abstract}

Keywords: death, symbolism, concept, semantic frame, figurative meaning, metaphor, negative connotation.

\section{Introduction}

The present discussion focuses on the expressions pertaining to the lexical frame of DEATH AND DYING containing the lexemes death, dead, and to die. It attempts to arrive at the underlying metaphorical meanings embedded in the analysed semantic group. Prior to the analysis of the collected material, basic information relating to the symbolism of death is presented, including also brief references to cultural and religious issues. The understanding of metaphorical language derives from cognitive linguistic literature (Kövecses 2010; 2015; Lakoff \& Johnson 1980; Lakoff \& Turner 1989; Ungerer \& Schmid 1996) pointing to the metaphors of life and death. Wierzbicka $(1996 ; 2004 ; 2010 ; 2014)$ presents the concept of death as a semantic and conceptual prime. In the contribution, the salient characteristics of semantic frames are briefly outlined. 


\section{Materials and methods}

The lexicon of death is formed by a substantial number of phrases and expressions. For the purpose of current analysis, various lexicographic sources have been referenced, including general dictionaries, dictionaries of idioms, dictionaries of euphemisms as well as dictionaries of allusions. The material is presented in three subsections, i.e. dead, death, to die, in which expressions and phrases containing the respective lexemes are listed and their definitions and meanings are provided. For clarity, the material is arranged in alphabetical order. Discussion of underlying meanings is provided within respective sections and the main observations are presented in the Concluding remarks.

\section{Death in various cultures: symbolism and beliefs}

The problem of the end of life, passing, and burying the dead, has always been a cultural taboo and the sacred in western civilisations. Death is also frequently referred to euphemistically in order to avoid naming the absolute, but also to conceal something people are afraid of. It is primarily defined in a dictionary as "the end of the life of a person or animal" (LDCE 2012: 434). The definitions may vary depending on the perspective that is taken to denote the issue. Hence, it will be diversely named and explained by various experts, i.e. in medicine, law, philosophy, anthropology, and other fields.

Biedermann (1996: 91) offers an extensive discussion of the symbols of death. In Neolithic period, death was portrayed as concentric circles on water, which "suggest ripples in the surface of the lake when an object is dropped into the water, and thus seems to symbolise the descent of the soul into the waters of death". Thus, the end of life was associated with passing to the water stretches surrounding the world of the living. The most typical symbols of death are skeletons and skulls and "from the Middle Ages onward, "living" skeletons have been featured in descriptions of the dance of death, which presents death as the great leveller, the equalizer of fortunes". There are also other objects often featured alongside. Biedermann (1996: 91) states as follows: 
"The old symbol of the death ship becomes in Greek art a "church ship" with anchor, cross (as a mast), and dove ([...] leading the way to paradise). The olive branch, as a symbol of peace, is also included, as are the snail (sleeping in its grave-like shell) and the butterfly, traditional symbols of resurrection; a wreath symbolises the reward in heaven for a life of devotion on earth. The scythe of the Grim Reaper [...] represents the cutting off of life; at times he also carries a bow and arrow (weapons of death) or an hourglass [...], a reference to the limited span of a person's life on earth".

The symbolic colour of death is black, however, it is replaced by white in the Far East. Moreover, as suggested by an encyclopaedia (OJLS 2007: 749-750), in European tradition there are numerous symbolic representations of the concept in question, including, among many others, an armed woman with bat wings and hawk claws, her hair let down; a skeleton wrapped in velvet and holding masks depicting various faces of death; an extinguished torch; a blown candle; a shattered column; an urn with a draped cloth; ruins, etc. It is also interesting to note that Slavic peoples consider death to be female, while the Germanic ones view it as male.

It is essential to point out that in British folklore there are various omens of death. Alexander (2006: 64) states that:

"[H] arbingers in various forms that warn of an approaching death were not uncommon [...]. For ordinary folk it might have been four crows flying over a cottage or a robin tapping with his beak on the window of a sick room, but some aristocratic families had their own particular portents. In Scotland a number of families were warned that one of their number was about to die by the loud lamentations of their own resident Glaistig, the Scottish version of the Irish Banshee ${ }^{1 " .}$

As stressed by the author, various places seemed to have their own instances of events, animals, and objects whose presence or appearance was to foretell misfortune.

This approach clearly is not a religious one and it originates in folk traditions. However, as noted by MacCulloch in the Introduction to The book of common prayer, there are certain "rites for coping with sickness and death" (1999: xix). The book itself is 
considered "one of the most important books in the English language. This is not because it is an incomparable road to heaven [...], nor even because it remains in formal terms the standard liturgy through which the established Church of England leads a nation in worshipping God. Rather, it is important as one of a handful of texts to have decided the future of a world language" (MacCulloch 1999: ix). According to the Christian faith, death is related to life and even though death is seen as the end of life, they are conversely related as well, i.e. the death is considered to be the beginning of the new, eternal life. This is reflected in the prayers presented in one of the chapters of the above-mentioned source titled 'The order for the burial of the dead'. Quoting after St John II. 25, 26, "I am the resurrection and the life, said the Lord: he that believeth in me, though he were dead, yet shall he live: and whosoever liveth and believeth in me shall never die" (BCP 1999: 216).

Nevertheless, it needs to be stressed that death is portrayed as the finalisation of life, which is reflected not only in literary pieces but also numerous works of visual art. As defined by the Longman dictionary of contemporary English, Death is "a creature that looks like a human skeleton, used in paintings, stories, etc. to represent the fact that people die" (LDCE 2012: 434). For instance, in Saint Peter's Basilica in the Vatican City the tomb of Pope Alexander VII by Bernini metaphorically depicts death. According to an Internet source (St. Peter's basilica, s.a.), "[i]t occupies an awkward position, being set in a niche above a doorway into a small vestry" with the doorway employed symbolically. The grand sculpture is described as follows:

"Pope Alexander kneels upon his tomb, facing outward. The tomb is supported on a large draped shroud in patterned red marble, and is supported by four female figures ${ }^{2}$, of whom only the two at the front are fully visible. They represent Charity and Truth. The foot of Truth rests upon the globe of the world, her toe being pierced symbolically by the Thorn of Protestant England. Coming forth, seemingly, from the doorway as if it were the entrance to a tomb, is the skeletal winged figure of Death $^{3}$, its head hidden beneath the shroud, but its right hand carrying an hourglass stretched upward towards the kneeling figure of the pope". 
More specifically, "the figure of Death is represented in gilded bronze, shrouded in a billowing drapery of Sicilian jasper. He raises an hourglass to symbolise that time has passed. The hourglass is also an artistic symbol of "memento mori" [translated from Latin as] "remember you will die" (Tomb of Pope Alexander, s.a.). The Death is believed to be communicating the message I was what you are, you will be what I am. Thus, the end mingles with the beginning.

Various customs, beliefs, and myths related to death and burial ceremonies are reflected in the languages that diverse communities use to communicate. As pointed out in various sources (e.g., Kowalski 2007: 550-556; OJLS 2007: 749-751), death generates a variety of forms of behaviour, which are acceptable and practised in one community and can be considered surprising or strange by another. However, irrespective of the treatment of the process and the burial rites involved, in most cultures people experience fear in relation to death. It is considered a strict taboo with a whole system of rules. According to Kowalski (2007: 551), in traditional cultures death and dying correspond to wearing out, destruction, losing primeval properties as well as life energy, original shape, form, and quality, which are the exponents of the status of an object, plant, animal, being, and the world. This results from the destructive activity of time, which is regarded as the basic quality of the human world and existence. Paradoxically, the effect is the death delivering form limitations and transferring the dead into the land devoid of passing, sickness, and death. Dying also means entering the unknown land of the dead, which is free from the effects of passing time. Beyond the boundary of the human world lies the area of the sacred, which is radically different from human reality.

The present discussion focuses on the linguistic representations of the concept of DEATH, therefore the cultural or religious issues have only been briefly highlighted and shall not be discussed in more detail. 


\section{Representation of 'death' in language}

Language, as pointed out by Wierzbicka (1992: 22), is not only "the best mirror of the human mind" but also of varied human cultures, and "it is through the vocabulary of human languages that we can discover and identify the culture-specific conceptual configurations characteristic of different peoples of the world". She also believes it is possible to spell out 'the alphabet of human thoughts', i.e. "the basic conceptual framework with which human beings operate". Owing to the fact that languages vary, so do the meanings embedded in certain lexical exponents of diverse vernaculars and concepts they represent.

Death is a natural phenomenon and it affects all living creatures. It is a universal of human experience. As noted by Wierzbicka (1996: 86-87), LIVE (ALIVE) can be considered a semantic primitive, for the concept of 'living' cannot be defined in simpler terms. Alternatively, "if we accept that 'life' is a simple, irreducible concept, many other concepts can be defined in terms of it", such as, for instance, the concepts relating to death. In her later publications (e.g., Wierzbicka 2004; 2010) she includes DIE alongside LIVE as a semantic prime for the conceptual primes of 'life and death'. The existence of those conceptual primes is supported by the fact that "as empirical crosslinguistic investigations indicate, all languages have words for "live" and "die"" (Wierzbicka 2014: 29).

Incidentally, in linguistic research one of the analysed and discussed constructs is dead metaphors. As pointed out by Ungerer and Schmid (1996), dead metaphor refers to certain linguistic forms whose figurative meaning has become conventionalised and lexicalised. Owing to recurrent association with a particular linguistic form, the nonliteral, metaphorical meaning of a lexical unit has become conventionalised in the given language community and, as a result, lexicalised as an individual sense of the lexical unit. The metaphor is 'dead' when "the metaphorical force of the word is no longer active" (1996: 117). Kövecses (2010: xi) points out that dead metaphors are considered to "have been alive and vigorous at some point but have become so 
conventional and commonplace with constant use that by now they have lost their vigour and have ceased to be metaphors at all". Nevertheless, he claims that the fact those constructs are used with ease does not mean they are devoid of vigour and are thus dead. He believes the opposite is true, as such spontaneous use of the metaphors testifies to the fact that they govern human thought and this property renders them "alive". Whether the linguistic expressions analysed in the present discussion are dead metaphors remains yet to be seen.

In cognitive linguistics, a concept, also referred to as representation, is defined by Evans (2007: 31) as:

"The fundamental unit of knowledge central to categorisation and conceptualisation. Concepts inhere in the conceptual system, and from early in infancy are redescribed from perceptual experience through a process termed perceptual meaning analysis. This process gives rise to the most rudimentary of concepts known as an image schema. Concepts can be encoded in a language-specific format known as the lexical concept. While concepts are relatively stable cognitive entities they are modified by ongoing episodic and recurrent experiences".

DEATH is a concept, which entails a number of phenomena, activities, and objects. It is also used in metaphorical language featuring the classical orientational metaphor (Lakoff \& Johnson 1980: 15) HEALTH AND LIFE ARE UP; SICKNESS AND DEATH ARE DOWN. The bases for such orientations originate in human physical and cultural experience, in which the sickness and death force people to lie down physically.

"Life is often conceptualised as a journey, as one moves from birth to death" (Hidasi 2008: 114). Thus, within a conceptual metaphor LIFE IS A JOURNEY (Kövecses 2015: 3; Lakoff \& Turner 1989: 3), death is considered to be the final stop. It is naturally viewed as the opposition to life, hence DEATH IS DEPARTURE (Lakoff \& Turner 1989: 1). The above-mentioned as well as numerous other metaphors are employed not only in literary language, but also with very high frequency in daily communication. 
Human experience can be organised in a number of ways. One of the cognitive constructs, or models systematising experience and knowledge, is a semantic frame. It was first defined by Fillmore (1975: 124) as "any system of linguistic choices - the easiest cases being collections of words, but also including choices of grammatical rules or linguistic categories - that can get associated with prototypical instances of scenes". As pointed out by Evans and Green (2006: 11) frames encompass "rich knowledge structures, which serve to call up and fill in background knowledge". Based on various sources it is possible to state that frames are a descriptive category in cognitive-semantic research, which designate complex knowledge structures. A frame is a system of closely connected and interrelated elements, which is embedded in a certain social and cultural context and is considered to be "a conceptual structure of a prototypical nature" (Uberman 2006: 42). Once an element of a frame is evoked, the entire frame is called into attention and becomes available.

The semantic frame DEATH AND DYING shall not be discussed here in detail as it is subject to analysis in a separate research study (Uberman, forthcoming). In the following sections the discussion will focus on the analysis of the phrases, expressions, and idioms containing the sense-bearing components forming the concept (compare for instance: Davydyuk \& Panasenko 2016), frame elements pertaining to the frame of DEATH AND DYING, such as dead, death, and to die. However few, the expressions containing the lexeme deadly are also noted.

\subsection{Dead}

According to Douglas Kozłowska in the reference work titled English adverbial collocations (1998: 76), the adverb dead means "definitely, really, undoubtedly, unquestionably".

The adjective dead as in 'the battery is dead', 'the line is dead' or 'radio went dead' means that it is "not working because there is no power". However, in the following examples: 'dead matches', 'dead glass / bottle' the adjective dead preceding the noun 
expresses the meaning "already used". Other meanings that can be listed are "boring because there is nothing interesting or exciting happening there", as in 'This place is dead after 9 o'clock', "not active or being used", as in 'The luxury car market has been dead in recent months', or "showing no emotion or sympathy", e.g., 'Jennie's eyes were cold and dead' (LDCE 2012: 430-431).

Dead ahead designates the meaning "directly or straight in front of one" (AHDI 1997: 253).

Dead-and-alive (BDPF 2002: 324) is equivalent to "dull, monotonous, as a dreary town or a boring person".

Dead bat (BDPF 2002: 324) is a phrase that refers to cricket and corresponds to "a bat held loosely so that the ball 'drops dead' when struck".

Dead and buried means to be "long forgotten" (HEI 1990: 97); "to be food for worms" (FDLNT 2000: 137); "(of some issue) definitely concluded, especially so long ago as to be nearly forgotten" (MS 1992: 74); also dead and gone "long forgotten, no longer in use" (AHDI 1997: 253).

If something is referred to as dead as a dodo, it is "extinct / obsolete" (HEI 1990: 97); "totally or assuredly dead; also finished" (AHDI 1997: 253). The latter source states that the reference is to an extinct bird and dates from the early 1900s. Similarly, dead as a doornail / mutton means "(emphatically) dead" (HEI 1990: 97); "totally or assuredly dead; also finished" (AHDI 1997: 253). The reference to doornail, according to American heritage dictionary of idioms (1997), dates from approximately 1350: "Its meaning is disputed but most likely it referred to the costly metal nails hammered into the outer doors of the wealthy (most people used the much cheaper wooden pegs), which were clinched on the inside of the door and therefore were "dead", that is, could not be used again". 
Dead as a herring is synonymous with "totally or assuredly dead; also finished" (AHDI 1997: 253). This expression dates from the $16^{\text {th }}$ century and, as noted by the reference work, it "no doubt alludes to the bad smell this dead fish gives off, making its death quite obvious" (AHDI 1997: 253).

Dead beat is equivalent in meaning to "exhausted" (HEI 1990: 97); "defeated" (AHDI 1997: 253). Brewer's dictionary of phrase and fable (2002: 324) additionally notes the meaning "completely exhausted; absolutely 'whacked', like a dead person who can no longer fight". Deadbeat, however, is "a lazy person or loafer; also, one who does not pay debts" (AHDI 1997: 253), or "a useless or socially undesirable person" (BDPF 2002: 324).

A dead cat bounce is the expression used with reference to "a temporary increase in the value of a security or currency of which the price has been falling but which remains overvalued" (DE 2002: 98). According to Room (BDMPF 2002: 175), the phrase comes from stock exchange jargon and it describes "a temporary recovery in share prices after a substantial fall, caused by speculators buying to cover their positions. A live cat on falling will spring up or 'bounce back', but a dead one will not, although it may seem to do so".

Dead centre (BDPF 2002: 324) corresponds to "the exact centre". However, referring to something as on dead centre (TDAI 1997: 86) means that it is exactly correct.

Dead certainty is the same as "absolute certainty" (HEI 1990: 97); also dead cert (BDPF 2002: 324).

A dead dog is synonymous with "something utterly worthless" (BDPF 2002: 324).

Dead duck refers to "something that is finished / over with" (HEI 1990: 114), "something of no further use or interest" (BDPF 2002: 324), or "a plan, idea, etc. that 
is not worth considering because it is very likely to fail" (LDCE 2012: 431). Thus, to be a dead duck means "to have failed" (MS 1992: 98). American heritage dictionary of idioms specifies two senses of the phrase, i.e. "1. a person doomed to failure or death; a hopeless case; 2. a useless, worthless or outmoded person or thing [...]. Some speculate that this slangy term comes from the old saying, "Never waste powder on a dead duck"'" (AHDI 1997: 254).

Dead drunk conveys the meaning "very drunk (to the point of unconsciousness)" (HEI 1990: 97). According to American heritage dictionary of idioms (1997: 254), the phrase alludes to "the immobility and insensitivity of actual death". Similarly, down among the dead men (DE 2002: 113) expresses the sense "drunk".

Dead end defines "[a] situation from which no progress can be made" (HEI 1990: 121); also "a passage that has no exit" (AHDI 1997: 254). It is an element of the following phrases: come to a dead end or reach a dead end (LDCE 2012: 431). When you come to a dead end (TDAI 1997: 308), you "come to an absolute stopping point". Hence, dead-end job is described as a "job with no prospects of promotion" (HEI 1990: 210); also a dead-end position (MS 1992: 97) "a job with no prospects of advancement". To run into a dead end is equivalent in meaning to "get nowhere in an investigation" (MS 1992: 98). Dead end kids (BDMPF 2002: 175) is an expression designating "children from poverty-stricken back streets for whom the future seems to hold little promise".

Dead fire (BDPF 2002: 324) refers to "corposant, believed at one time to presage death".

Referring to someone as dead from the neck up means they are "foolish / stupid" (HEI 1990: 97); "extremely stupid" (AHDI 1997: 254); where the death of the brains metaphorically signifies lack of intelligence. 
Dead hand (BDPF 2002: 324) is a metonymic phrase, which stands for "an oppressive influence, especially that of a deceased person". The dead hand of something (LDCE 2012: 431), on the other hand, signifies "something, which stops or slows your progress, especially a strong influence". Wilkinson states that the dead hand of the past (TTEM 2002: 642) represents the meaning: "those restraints of a long-established tradition that inhibit any reform or improvement".

The term deadhead (BDPF 2002: 324) designates "a person who makes use of a free ticket for a theatre, cinema, train or the like". However, the verb to deadhead (LDCE 2012: 431) refers to the process of "remov[ing] the dead or dying flowers from a plant".

Dead heat describes "race / competition, in which two (or more) contestants are exactly level at the finish" (HEI 1990: 97); "a tie" (BDPF 2002: 324). As noted by the American heritage dictionary of idioms (1997: 254), the term had its origin in $18^{\text {th }}$ century British horse racing and was never used with reference to other types of competitions. Thus, in a dead heat (TDAI 1997: 283) used with reference to finishing a race corresponds to "at exactly the same time; tied".

The phrase dead in someone's or something's tracks (TDAI 1997: 308) is equivalent to "exactly where someone or something is at the moment; at this instant". The source additionally points out that this usually has nothing to do with death, and the phrase is often used with stop.

Dead in the water (AHDI 1997: 254) is an idiom originating in the maritime lexicon, i.e.: "originally referring to a crippled ship, this colloquialism was soon applied more broadly" with the meaning "unable to function or move; inoperable"; "unable to function properly" (BDMPF 2002: 175), to be dead in the water (LDCE 2012: 431) designates a plan or idea, which is "unlikely to continue successfully". Room (BDMPF 2002: 175) explains that the reference in the phrase "is not to a drowned person but to a ship that is unable to move for some reason, either because there is no current or no 
wind or because her engine has failed". Dead water (BDPF 2002: 326) refers to "eddying water that closes around a ship's stern as it passes through the water".

A dead language (BDPF 2002: 325) is "a language that is no longer spoken, such as Latin".

Dead letter describes "1. [a]n unclaimed or undelivered letter that is eventually destroyed or returned to the sender. 2. [a] statute or directive that is still valid but in practice is not enforced" (AHDI 1997: 254). However, dead letter box / drop (BDMPF 2002: 175) is a term used in espionage to designate "a place where messages can be left by one person for another without either of them meeting".

Deadline is defined as "time, by which something must be completed" (MS 1992: 98). As explained in Brewer's dictionary of phrase and fable (2002: 325), "this sense of strict demarcation derives from the 'deadline' round a military prison camp. The phrase was coined in the notorious Confederate prison-of-war camp, Andersonville, during the American Civil War [...]. Some distance from the peripheral wire fence a line was marked out and any prisoner crossing this line was shot on sight". Thus, if deadline is understood as the time by which some task has to be finalised, to meet the deadline corresponds to "have something ready on time" (HEI 1990: 97).

Deadlock metaphorically describes "a state of things so entangled that there seems to be no solution" (BDPF 2002: 325) or "a situation, in which a disagreement cannot be settled" (LDCE 2012: 431). Hence, at a deadlock represents the meaning "unable to move in any direction. Often said of an impasse in negotiations or an apparently insoluble problem" (TTEM 2002: 194).

Dead loss is a description of "a total loss" (TDAI 1997: 213); but also "a worthless person or thing; also, an utter waste of time" (AHDI 1997: 255). 
Dead man's hand (WMDA 1999: 144) signifies "really rotten luck; a sign of unforeseen and unintended disaster". The phrase originated in the card-playing lexicon, as it refers to "the poker hand held by Wild Bill Hickok at the moment he was shot in the back by Jack McCall in Deadwood, South Dakota, on August 2, 1876. There is some controversy about the cards Hickok was holding, but they are thought to have been black aces and black eights, two pairs, and the combination became known as "the dead man's hand". Another version has it as two jacks and two eights".

Dead man's handle (BDPF 2002: 325) refers to "a handle on the controls of an electric train, so designed that it cuts off the current and applies the brakes if the driver releases his pressure from illness or some other cause. It is now officially called a driver's safety device, and it is usually in the form of a plate depressed by the foot".

Dead man also dead soldier (AHDI 1997: 255) designates "an empty liquor, wine, or beer bottle", "an empty bottle of wine or spirits" (DE 2002: 98); dead men "empty bottles" (HEI 1990: 248); also dead marines; called so because "when the 'spirit' is out of the bottle, it is dead"(BDPF 2002: 325). The indirect reference to dead representing the meaning "drunk" can be also noted, as in down among the dead men.

The expression dead man's shoes refers to a "job opportunity provided by somebody's death or retirement" (HEI 1990: 97).

Dead march (BDPF 2002: 325) is "a funeral march", i.e. a piece of music performed at funeral.

Dead men tell no tales is a phrase, which corresponds to "one cannot be incriminated by somebody who is dead" (HEI 1990: 386), as the person will definitely not say anything anymore. 
When one is referred to as dead meat (BDMPF 2002: 176), it means that they are "in serious trouble, as if as good as dead. 'Dead meat' is $19^{\text {th }}$ century slang for a corpse". This expression also designates "a human corpse" (DE 2002: 98).

The expressions dead on / dead right (BDPF 2002: 325) both correspond to "exactly right".

If a person is said to be dead on one's feet, they are "exhausted; worn-out"; if something is dead on its feet, it is considered "no longer useful" (TDAI 1997: 338).

Dead on one's feet as well as dead tired are phrases meaning "very weary". As noted by the American heritage dictionary of idioms (1997: 255), "the use of dead for "tired to exhaustion" dates from the early 1800s, and dead on one's feet, conjuring up the image of a dead person still standing up, dates from the late $1800 \mathrm{~s} "$.

Dead of refers to "the period of greatest intensity of something, such as darkness or cold" (AHDI 1997: 255); hence dead of night is the "darkest part of the night" (HEI 1990: 97), and dead of winter describes "the coldest part of winter" (AHDI 1997: 255).

Dead-pan is synonymous with "lacking any expression" (HEI 1990: 97); "emotionless, expressionless, of a person's face or manner. 'Pan' here is a colloquial word meaning 'face'" (BDPF 2002: 325). The Longman dictionary of contemporary English (LDCE 2012: 432) provides a different definition, i.e. "sounding and looking completely serious when you are saying or doing something funny: deadpan voice / expression etc. deadpan humour".

Dead reckoning (LDCE 2012: 432) designates a method of "calculating the position of a ship or aircraft without using the sun, moon, or stars". 
Dead ringer (for somebody) describes "a double / somebody who looks exactly the same" (HEI 1990: 97); "an exact counterpart" (AHDI 1997: 255). Similarly, dead spirit of someone (BDPF 2002: 325) is "the exact counterpart; [...] spitting image".

Dead set against (AHDI 1997: 255) stands for "completely opposed to", with dead representing the meaning utterly.

Dead shot (BDPF 2002: 325) is a description of "a person who shoots extremely accurately. A legendary example is William Tell".

When somebody is said to be dead to something (DE 2002: 98), they are "recklessly ignoring" something. Thus, dead to rights means "with no excuse" (HEI 1990: 320); "in the act of committing an error or crime, red-handed". The source explains the use of to rights in the sense of at once (AHDI 1997: 255). Hence, to have someone dead to rights is synonymous with the meaning "to have proven someone unquestionably guilty" (TDAI 1997: 258).

A person who is dead to the world is "fast asleep / unconscious" (HEI 1990: 97); also "tired, exhausted, sleeping soundly" (TDAI 1997: 144); "in a deep sleep or a state of exhaustion or intoxication, so that one is totally unconscious of one's surroundings" (BDPF 2002: 326). It is impossible to get this person's attention hence they are referred to figuratively as dead.

Dead weight corresponds to "a heavy or oppressive burden. [...] This term alludes to the unrelieved weight of an inert mass" (AHDI 1997: 256). It is also applied to "[t]he weight of something without life" or "an oppressive thing or person" (BDPF 2002: 326); "someone or something that prevents you from making progress or being successful". 
Dead wood is a phrase describing "useless appendage / person" (HEI 1990: 97); "useless people or things" (BDPF 2002: 326). Hence, to get rid of the dead wood (MS 1992: 98) is equivalent in meaning to "terminate the services of unsatisfactory personnel". Also similarly, to cut out the deadwood stands for the meaning "to remove unproductive persons from employment" (TDAI 1997: 270).

The baptism for the dead (BDPF 2002: 92) was "formerly a kind of vicarious baptism of a living person for the sake of one dead, regarded by the early Christians as a heretical and superstitious custom".

Be in (deadly) earnest means to "be very serious" (HEI 1990: 117); also in dead earnest corresponds in meaning to "serious, determined" (AHDI 1997: 526).

Beat a dead horse / flog a dead horse means "to misguidedly do something patently useless" (MS 1992: 125); "try to revive interest in a hopeless issue. [...] From the 1600s on, the term dead horse was used figuratively to mean "something of no current value", specifically an advance in pay or other debt that had to be worked ("flogged") off" (AHDI 1997: 78). Exerting force over an immobile and non-responsive animal is counterproductive and is doomed to failure. Behaving in a similar manner will be equally unsuccessful.

Come to a dead stop is synonymous with "halt abruptly" (HEI 1990: 373). The lexeme dead is used for emphasis and suggests a sudden action.

Cut somebody dead corresponds to the sense "deliberately ignore somebody (in public)" (HEI 1990: 92); "to snub a person" (MS 1992: 96); "pretend not to see or recognise someone" (AHDI 1997: 246).

To drop dead (TDAI 1997: 92) means to die suddenly. However, the exclamation drop dead! stands for "go away!" (HEI 1990: 97); "go away, I want no dealings with you" 
(MS 1992: 98). The phrase is "an expression of anger, rejection, or indignation toward someone" (AHDI 1997: 290). Interestingly enough, the adjective and adverb dropdead is not insulting in nature and it means: "dazzling, awe-inspiring" (AHDI 1997: 291) and originated in slangy journalism of the 1960s. A drop-dead list (DE 2002: 116) refers to "a list of names of people to be dismissed from employment".

The expression enough to wake the dead suggests that the produced sound is "very loud" (HEI 1990: 97).

To go dead stands for "cease working" (HEI 1990: 97) and clearly designates lack of energy or any driving force.

Kill some proposal stone dead (MS 1992: 98) refers to the meaning "abandon some proposal completely".

Knock dead corresponds to the sense of "greatly amuse, astonish, or thrill someone" (AHDI 1997: 589); "to put on a stunning performance or display for someone" (TDAI 1997: 16).

Leave others for dead (MS 1992: 98) is the same as "to be vastly superior". However, to leave someone for dead (TDAI 1997: 1) suggests "to abandon someone as being dead".

Let the dead bury their dead (BDPF 2002: 690) is an expression of biblical origin conveying the sense "[1]et bygones be bygones. Don't rake up old scores and dead grievances".

When someone is said to make a dead set at, the meaning expressed by the phrase is to "purposefully attack / approach" (HEI 1990: 97). 
The phrase more dead than alive is a representation of lowly state, designating the meaning "exhausted, in poor condition" (AHDI 1997: 691); "exhausted, in very bad condition, near death" (TDAI 1997: 144). However, as noted by the author, this is almost always an exaggeration.

Over my dead body is an expression used with the meaning "only if my most vigorous opposition fails" (HEI 1990: 97); "in no way, under no circumstances" (AHDI 1997: 789); "never" (MS 1992: 66).

Play dead / possum corresponds to "remain motionless and pretend to be dead" (HEI 1990: 298). As explained by Wilkinson in his Thesaurus of traditional English metaphors (TTEM 2002: 208), pretending to be dead is one of the survival tricks adopted by animals, opossum in this case.

Quick and the dead (AHDI 1997: 860) is a phrase, which stands for "the living and the dead". As specified by the Online etymology dictionary, cwic in Old English meant 'alive', 'living', 'animate' (hence also the phrase to cut to the quick). The MerriamWebster's dictionary of allusions (1999: 451) points to the fact that the quick and the dead is "[a] New Testament phrase referring to the Day of Judgement, when Jesus Christ will return from heaven to judge everyone, both the quick and the dead, and will determine who will have eternal life and who will be damned". Wilkinson (TTEM 2002: 340) presents the saying let the quick horse pull the dead horse out of the mire corresponding to the sense "mix, share or offset good with bad, smooth with rough".

Refuse to / wouldn't be seen dead in means to "be too ashamed / embarrassed to do something" (HEI 1990: 97). American heritage dictionary of idioms (1997: 179) also suggests another version of the phrase, i.e. wouldn't be caught dead / seen dead with the synonymous meaning "would have nothing to do with; detest". Wilkinson (TTEM 2002: 642) adds a phrase I wouldn't be seen dead (in a ditch) in it!, which is said of clothing, vehicle, etc. "considered to be well below the speaker's standard". Renton 
(MS 1992: 97) additionally lists an expression, which employs a somehow reverse situation, i.e. I wouldn't be caught dead without some object to represent the sense "I regard some object as very important".

When a man is said to skin off all dead horses (DE 2002: 364-365), he marries his mistress. Wilkinson in his thesaurus suggests that the phrase means "finish work that has already been paid for" (TTEM 2002: 341). The latter rendition does somehow explain the humorous sense suggested by Holder in his Dictionary of euphemisms (DE 2002: 364-365) with reference to marriage.

Stone dead is used to designate the meaning "(completely) dead" (HEI 1990: 373), as neither of the entities exhibit any features of life.

Stop dead means the same as "come to an abrupt halt" (HEI 1990: 373). However, to stop dead in one's tracks or on a dime as well as stop cold is an expression noted by the American heritage dictionary of idioms (1997: 1007) with the meaning "halt suddenly, come to a standstill".

If someone is appearing or assumed to be dead, they can be said to be taken for dead (TDAI 1997: 93).

Deadly (LDCE 2012: 431-432) is the adjective, which stands for "likely to cause death; lethal", as in 'a deadly poison', 'a deadly weapon', 'deadly disease', 'deadly virus'; "causing harm in a very effective way" as in 'with deadly accuracy', or "like death in appearance" as in 'His face had a deadly paleness'. However, a deadly enemy (LDCE 2012: 431-432) is "someone who will always be your enemy and will try to harm you as much as possible". 
The seven deadly sins / capital sins (BDPF 2002: 326) designate "pride, covetousness, lust, envy, gluttony, anger, and sloth". The reference is religious and the listed concepts or forms of behaviour are what a devout person should largely avoid.

\subsection{Death}

At death's door is equivalent in meaning to "on the point of death" (HEI 1990: 108); "very ill and likely to die" (LDCE 2012: 434). According to the American heritage dictionary of idioms (1997: 48), the phrase similarly means "on the point of dying, very ill". The source also explains that "the association of death with an entry way was first made in English in the late 1300s, and the phrase itself dates from the mid-1500s. Today it is often used as an exaggeration of ill health".

To be on one's death bed (MS 1992: 324), when referring to an organisation or a piece of equipment, means "to be about to cease functioning". Death-bed repentance (TTEM 2002: 857) designates "change of policy made too late to be of either use or credit". Hence, death bed evidently represents the final stage of functioning or being too late to make a significant change.

To be the death of somebody corresponds to "be the cause of (somebody's) death, or cause great amusement, or annoyance / trouble" (HEI 1990: 98) or is "used to say that someone is causing you a lot of worry and problems" (LDCE 2012: 434).

Bitter death (FDLNT 2000: 25) refers to death accompanied by severe pain and suffering.

Death blow describes "an action or event that makes something fail or end" (LDCE 2012: 434); "final destructive event; the end to hopes, plans, etc." (TTEM 2002: 92).

To slowly bleed to death (MS 1992: 324) means "to be heading in gradual steps toward total ruin". 
Between life and death (TDAI 1997: 45) is a phrase, which designates the meaning "in a position where living or dying is an even possibility".

Bore to death (bore to tears / bore stiff / bore the pants off) (AHDI 1997: 118) means to "weary someone through extremely dull talk or uninteresting action". Hence, someone who is bored to death (TDAI 1997: 46) is "very bored".

Catch one's death (of cold); is a spoken old-fashioned phrase used for warning someone "they are likely to become ill because they are wet or cold" (LDCE 2012: 434); "catch a chill / very bad cold" (HEI 1990: 98).

The phrase certain as / sure as death and taxes (AHDI 1997: 257) describes a situation, state of affairs "bound to occur, inevitable.[...] This phrase was invented by Benjamin Franklin in a letter (1789) and has been repeated ever since, the government's recurring need for revenue probably assuring its continued popularity".

Cling / hold on like a limpet / grim death means to "hold on to something with determination" (HEI 1990: 71). Also, to hang on like grim death (BDPF 2002: 546) means "to cling tenaciously, literally or metaphorically; to refuse to be shaken off, as death persists once it has marked down its victim". Hence, the expression like grim death (BDPF 2002: 699) conveys the meaning "as if one's life depended on it".

Dance of Death (BDPF 2002: 316) is the phrase used with reference to "an allegorical representation of Death (usually a dancing skeleton or corpse) leading people to the grave in order of social precedence".

If one wants to or does dice with death, it means that they "take a (severe) risk" (HEI 1990: 102). This phrase evokes the image of death playing a board game with someone. The outcome of such a game is hardly predictable, thus risk is involved. 
Death by a thousand cuts (MWDA 1999: 145) describes "a slow death by the torture of many small wounds, none lethal in itself, but fatal in its cumulative effect". As noted by the source, this form of torture was "a form of execution in ancient China, reserved for the most heinous crimes".

Death cookie (FDLNT 2000: 75) designates "a frozen lump of snow on a ski run"; which, unlike most cookies, is highly undesirable and its presence is not at all appreciated by skiers.

Death's head (BDPF 2002: 327) is "a skull". Room further notes that "prostitutes and procuresses used to wear a ring bearing the impression of a death's head in the time of Queen Elizabeth I". Unless such rings were worn willingly, this could be seen as the form of stigmatising certain individuals possibly so that they might be recognised by other members of the society.

Death knell is "something that indicates impending failure" (AHDI 1997: 257); "an event that heralds the end or destruction of something" (BDPF 2002: 327). Hence, to sound the death knell of something (MS 1992: 324) is an equivalent of "to indicate the impending end of something".

Death on stands for the meaning "very effective against; also, very fond of" (AHDI 1997: 257). The phrase is one of very few examples whose meaning is not entirely negatively valued.

Death row (BDPF 2002: 327) refers to the penitentiary system and designates "a prison block or section for prisoners sentenced to death".

Death sentence (LDCE 2012: 434) is literally the official punishment of death, ordered by a judge. The metaphorical meaning of the phrase designates "something such as an 
illness that makes you sure you will die" or "an action or decision that is very harmful to someone or something".

Death squad (LDCE 2012: 434) designates "a group of people who have been ordered to kill someone's political opponents".

Death throes (LDCE 2012: 434) refer to "the final stages before something fails or ends", but also in a literary sense they are "sudden violent movements that people sometimes make when they are dying".

Death trap is the name given to a "place in which one is in danger of being seriously injured / killed" (HEI 1990: 98). This could be a building, a vehicle or a situation.

Death warrant (BDPF 2002: 327) is "an official authority to carry out an execution"; but also "something that is likely to cause you very serious trouble, or even your death" (LDCE 2012: 434). Hence, to sign somebody's death warrant corresponds to the meaning to "commit an action that results in somebody's death or downfall" (HEI 1990: 98); also, do irreparable harm (AHDI 1997: 950). In addition, to sign one's own death warrant (MS 1992: 324) corresponds to "foolishly do something, which is inevitably bound to lead to utter disaster".

A death wish (MS 1992: 324) is "the contemplation of action so foolish that it is likely to lead to utter disaster". Also, as noted by Room (BDPF 2002: 327), it is "a wish, often unconscious, for a person's death, either that of oneself or of another"; "a desire to die" (LDCE 2012: 435).

To die a natural death (MS 1992: 324) is a meaning referring to the situation where something or someone is no longer relevant "by virtue of changed circumstances or the effluxion of time", while sudden death (MS 1992: 324) corresponds to "instantaneously or without phasing in". 
Do to death corresponds to "overdo / overexpose" (HEI 1990: 98), while the expression to death (AHDI 1997: 1088) stands for "to an extreme or intolerable degree". The phrase is used as an intensifier, it is employed to "emphasise that a feeling or emotion is very strong" (LDCE 2012: 434). However, it is also applied to say that "an action is continued with a lot of effort and for as long as possible" (LDCE 2012: 434), which seems to originate in the idea that death is the end of a lifecycle of considerable length, involving substantial effort while it lasts and is still in progress.

Dogs howl at death (BDPF 2002: 327) is a widespread superstition that the animals in question perform such action when the end of life approaches.

To feel like death warmed up means to "feel exhausted / ill" (HEI 1990: 98); also look like death warmed up similarly meaning "look or feel very ill or exhausted" (AHDI 1997: 640); also look like death warmed over "to look as pale as a dead person" (TDAI 1997: 25).

In at the death (finish / kill) corresponds to the sense "present at the very end" (HEI 1990: 98); "to be present at the conclusion of something" (MS 1992: 324); also "involved in or present at the end, especially a disastrous end but sometimes merely a climax of an important event. [...] These expressions originally alluded to hunters and hounds being present at the death of a fox they had run to ground" (AHDI 1997: 519).

Living death (BDPF 2002: 316) describes "a state of hopeless misery", and pale as death stands for "very pale" (HEI 1990: 98).

To put to death (AHDI 1997: 856) is equivalent to "kill, execute", while to scare to death (AHDI 1997: 909) means to "terrify, make one panic". The source notes that the phrase alludes to the fact that "a sudden fright can precipitate cardiac arrest". 
To be sick to death of corresponds to "thoroughly fed up" (HEI 1990: 98); also sick and tired or sick or tired to death means "thoroughly weary or bored. [...] These hyperbolic expressions of exasperation imply one is weary to the point of illness or death" (AHDI 1997: 947).

When someone is starved / starving to death (FDLNT 2000: 341), they are very hungry. When used in this figurative meaning the phrase is an obvious exaggeration.

To struggle to the death (TDAI 1997: 56) is "a bitter struggle to the end or to death".

If one is tickled to death they are "highly amused" (HEI 1990: 98); "delighted" (AHDI 1997: 1079). Similarly, thrilled to death / to pieces (AHDI 1997: 1071) means "give great pleasure, delight".

To be tired to death / out (AHDI 1997: 1086) means to be "exhausted".

The phrase to the death is defined as "until somebody is defeated or killed" (HEI 1990: 98); "until someone is dead" (LDCE 2012: 434). However, the Longman dictionary of contemporary English also presents the second sense, according to which to the death is synonymous with "until you achieve something even if it means that you suffer" (LDCE 2012: 434).

The phrase to work something to death expresses the meaning to "force something to work excessively, or overexpose something" (HEI 1990: 98).

Fate worse than death describes "something, which is most undesirable, or (of a woman) unwilling participation in sex" (HEI 1990: 135); "a highly undesirable occurrence, a misfortune" (AHDI 1997: 328).

Jaws of death is "place / point at which one is in danger of dying" (HEI 1990: 210). 
Kiss of death "something that brings about ruin" (HEI 1990: 217); "something intended to be helpful but resulting in total destruction" (MS 1992: 324); "an outwardly kind, well-intentioned action, but which brings disastrous consequences" (TTEM 2002: 854). The American heritage dictionary of idioms (1997: 587) notes that the phrase refers to "an action or relationship that is ultimately ruinous" and states that it originates in the biblical story. "This term alludes to the betrayal of Jesus by Judas Iscariot, who kissed him as a way of identifying him to the soldiers who came to arrest him [...]. It dates only from about 1940 but was previously called a Judas kiss".

The expression a matter of life and death describes "a crucial or urgent matter" (BDPF 2002: 754); "a very urgent issue, situation, or circumstance" (AHDI 1997: 676) and can be used both literally and metaphorically.

Mercy death (DE 2002: 253) is the term referring to "the murder of a patient thought to be terminally ill".

The phrase till death us do part is a part of marriage vows. According to Room (BDPF 2002: 316), it means "to separate effectually. The marriage service in the old prayer books had 'till death us depart', which has been corrupted into 'till death us do part'".

Wall of death (BDPF 2002: 1244) refers to "a fairground attraction consisting of a giant cylinder, around the inside walls of which a motorcyclist rides, often blindfolded". Wheel of death (BDPF 2002: 1259-1260), on the other hand, designates "a hazardous circus act, in which a performer spins in and on a large 'hamster wheel' as it is gradually lowered to the ground from a $50 \mathrm{ft}(15 \mathrm{~m})$ high wire".

Worried to death (also worried sick) (AHDI 1997: 1182) stands for "extremely anxious". The emphasis is evoked by the application of the element to death. 
When something is done or happens on the deathknock (MS 1992: 324), it happens "at the last possible moment", just as guests usually knock on the door right before they enter.

\subsection{To die}

To die is a verb representing various senses (LDCE 2012: 466), such as "to stop living and become dead"; "to disappear or stop existing"; or when talking of machines "to stop working".

To die a natural death (TDAI 1997: 92) means "to die by disease or old age rather than by violence or foul play".

If someone is (to be) dying to do something (MS 1992: 324), they are "extremely keen to do something".

To die for / be dying for (AHDI 1997: 262) means to "long for, desire excessively"; "to want something very much" (LDCE 2012: 466). To die for is also synonymous with "extremely good; so excellent or desirable that one is prepared to die for it". Hence, when exclaiming it's to die or it is to die for (AHDI 1997: 564), the person means "it's extraordinary; it's deeply appreciated and / or greatly desired", or "extremely nice, attractive, or desirable" (LDCE 2012: 466).

The phrase to die a / the death (LDCE 2012: 467) is used informally to refer to the sense "to gradually fail or be forgotten".

When one says I'd rather die, he or she says very strongly that they do not want to do something. However, when uttering I nearly died / I could have died one means that they "felt very surprised or embarrassed" (LDCE 2012: 466). 
To die hard means "not to give up easily" (MS 1992: 324); "take a long time to cease to exist or be dropped from consideration. [...] This idiom alludes to struggling against physical death". Therefore, diehards, is a term, which in political phraseology describes "those members of a party who refuse to abandon long-held theories and attitudes regardless of the changes that time and situation may bring" (BDPF 2002: 341). A diehard (LDCE 2012: 467) also describes "someone who opposes change and refuses to accept new ideas".

To die away / down (AHDI 1997: 262) corresponds to the sense "gradually diminish, fade, or subside; slowly come to an end".

When somebody is said to die for want of lobster sauce (BDPF 2002: 341), they "die or suffer severely because of some trifling disappointment, pique or wounded vanity".

To die in harness / die with one's boots on (AHDI 1997: 262; 263) refers to the sense "expire while working, keep working to the end" and both phrases seem to allude to soldiers who died on active duty. Room (BDPF 2002: 341) similarly suggests that $\boldsymbol{t}$ die in harness corresponds to the sense "to die working, while still in active employment or before retirement, like a draught horse that drops dead between the shafts of a cart, or the soldier who dies fighting in harness, i.e. armour". However, the meaning of the other phrase, namely to die with one's boots on, is considered synonymous to "to die a violent death, specifically by hanging", similarly to to die in one's shoes, meaning "to die a violent death, especially one on the scaffold" (BDPF 2002: 341). The violence of death, however, is not noted in the dictionary definitions provided by Spears (TDAI 1997: 92), who defines the idioms to die in one's boots and to die with one's boots on as "to go down fighting, to die in some fashion other than in bed; to die fighting". The idea appears to have been popularised by western movies, in which villains said they preferred death by gunshot or hanging to dying in bed.

To die in the last ditch (BDPF 2002: 341) means "to fight to the death or last gasp". 
To die of boredom (TDAI 1997: 47) is synonymous with "to suffer from boredom; to be very bored" and does not involve actual death.

To die laughing (AHDI 1997: 262) is understood as to "experience extreme amusement".

To die / wither on a vine corresponds in meaning to "decline or fade away at an early stage of development" (TDAI 1997: 131), or "to fail, in the planning stage, from lack of interest or involvement" (FDLNT 2000: 392). The metaphor employed in the expression refers to lack of attention from the labourers in the vineyard. Clearly, just as neglected grapevine tends to wither and bear no fruit, so a project can be ruined as a result of poor social or financial conditions involved.

To die off is an equivalent of to "perish one by one", while to die out means to "gradually become extinct" (AHDI 1997: 262).

To die like a dog (HEI 1990: 106) corresponds to the sense "have a shameful / undignified death".

To die with your knees bent (DE 2000: 104) is a phrase used in American English and designates the meaning "to be killed in an electric chair".

To cross one's heart (and hope to die) (TDAI 1997: 258) means "to pledge or vow that the truth is being told".

The expression to curl up and die (AHDI 1997: 241) is an equivalent of the meaning "retreat, collapse, die". 
Do or die (AHDI 1997: 274) corresponds to "exert supreme effort because failure is close at hand", meaning that "one will not be deterred by any obstacle"; "to make a final supreme effort; to try hard until one either wins or loses" (BDPF 2002: 350).

The saying Let us eat, drink, and be merry, for tomorrow we die (FDLNT 2000: 212) expresses the meaning "let's enjoy ourselves while we still have the chance"; enjoy the life while it still lasts.

Never say die is a phrase that is used to "encourage someone to continue doing something that is difficult" (LDCE 2012: 467), thus, it also means "don't ever give up, do not despair [...]. This maxim today is often used ironically and deprecatingly, for something that has already failed" (AHDI 1997: 705).

What did your last servant die of? (HEI 1990: 339) is a humorous way of saying "why don't you do it yourself?"

\section{Discussion and concluding remarks}

Death is a natural phenomenon, which is omnipresent. Its finality and irreversibility must have forced people to attempt to somehow 'tame' or 'humanise' the concept and become more familiar with it through repeated reference in language. Nevertheless, however much one may try to become familiar and get ready for one's own or someone else's death, it almost always seems sudden and unexpected. The number of expressions considered in the above discussion proves the immenseness of the task of analysing metaphorical language related to the topic of death and included in the frame of DEATH AND DYING.

Dead is often used for emphasis (e.g., dead silence, dead centre, dead cert, dead boing, etc.) but most often it signifies the state of not working (e.g., dead battery, dead link, line is dead, etc.) or the fact that something is no longer in use (e.g., dead letter, dead language, etc.). Moreover, dead is synonymous with trouble (e.g., drop dead, dead and buried, etc.), restriction and oppression (dead hand, the dead hand of the past, 
etc.), limitation to the progress (dead end, dead-end job, reach a dead end, dead in the water, go dead, etc.) or the state of being exhausted (dead beat, dead on one's feet, dead tired, more dead than alive, etc.). The analysed expressions also point to people or things being considered worthless (dead dog), useless (dead wood, cut out the dead wood, etc.), forgotten (dead and buried, dead and gone, etc.) finished or dead (dead as a dodo, dead as a herring, dead as a doornail, dead duck, etc.). Similarity between the state of being drunk or asleep, thus inattentive, and being dead, is illustrated by a number of phrases such as dead drunk, down among the dead men, dead to the world, dead soldiers, dead men, or dead marines.

The greatest proportion of the linguistic expressions involving the elements of the frame of DEATH AND DYING portray 'death' as a powerful force that cannot be stopped or avoided (e.g., sure as death and taxes, death row, death sentence, like grim death, etc.). The presence of the lexeme death in a phrase signifies some type of danger involved in the place or the activity performed (e.g., death trap, wall of death, wheel of death, etc.). It also foretells pain (e.g., bitter death, death by a thousand cuts, etc.), poor condition (e.g., at death's door, look like death warmed up, living death, pale as death, etc.), violence and oppression (e.g., fate worse than death, jaws of death, etc.) or serious trouble (e.g., be the death of somebody, slowly bleed to death, kiss of death, etc.). The use of the discussed lexical item in a phrase or expression designates extreme degree or overexposure (e.g., do to death, to death, bored to death, sick to death, etc.) as well as failure or finality (e.g., death knell, sign somebody's death warrant, put to death, etc.). It has to be noted that very few expressions employing death connote positively, designating amusement, delight or pleasure (e.g., tickled to death, thrilled to death), or being fond of something (death on).

The use of the verb to die entails great enthusiasm, appreciation, good quality or excellence, since one would be willing to sacrifice their life to get or do something (e.g., to die for, it's to die, to be dying to do something, etc.) and persistence (e.g., to die in harness, die with one's boots on, to die hard, etc.). However, in the majority of 
the quoted examples, the verb is used to designate peril (e.g., to die a natural death, to die off, to die out, to curl up and die, to die like a dog, to die on a vine, etc.).

It has to be pointed out that the discussion of the elements of the semantic frame DEATH AND DYING is not exhaustive. There are many more lexical items, phrases, and expressions, which need to be addressed and this attempt will be made in further research. However, from the available material it can tentatively be concluded that the concept of death (as exemplified by the addressed linguistic expressions) is generally negatively valued. Only few phrases carry a positive emotive load. Despite the fact that in many religions death is considered the end of earthy life and the beginning of the new better form of existence, Death still looks grim.

\section{References}

Alexander, M. (2006). A companion to the folklore, myths \& customs of Britain. Phoenix Mill: Sutton Publishing Limited.

Ammer, C. American heritage dictionary of idioms. (1997). Boston, MA.: Houghton Mifflin. (AHDI)

Biedermann, H. (1996). The Wordsworth dictionary of symbolism. Ware: Wordsworth Editions Ltd.

Brewer's dictionary of modern phrase and fable. (2002). Room, A. (ed.). London: Cassell Publishers.

Brewer's dictionary of phrase and fable. (2002). Room, A. (ed.). London: Cassell Publishers.

Davydyuk, Yu. \& Panasenko, N. (2016). Figuring the male and female: fire and water in Bradbury's (science) fiction. In Lege Artis, I(1), p. 4-74. DOI: 10.1515/lart-20160001

Douglas Kozłowska, C. English adverbial collocations. (1998). Warszawa: Wydawnictwo Naukowe PWN.

Evans, V. (2007). A glossary of cognitive linguistics. Edinburgh: Edinburgh University Press. 
Evans, V. \& Green, M. (2006). Cognitive linguistics: an introduction. Edinburgh: Edinburgh University Press.

Fillmore, C. (1975). An alternative to checklist theories of meaning. In Proceedings of the Berkeley Linguistic Society. Cogen, C., Thompson, H., Thurgood, G. \& Whistler, K. (eds.). Berkeley: Berkeley Linguistics Society, p. 123-131.

Harrap's English idioms. (1990). Bromley: Harrap Books Ltd.

Hidasi, J. (2008). Cultural messages of metaphors. In Metaphors for learning: crosscultural perspectives. Berendt, E.A. (ed.). Amsterdam-Philadelphia: John Benjamins Publishing Company, p. 103-122.

Holder, R. W. How not to say what you mean. A dictionary of euphemisms. (2002).

Oxford: Oxford University Press.

Kowalski, P. (2007). Kultura magiczna. Omen, przesąd, znaczenie. Warszawa: Wydawnictwo Naukowe PWN.

Kövecses, Z. (2010). Metaphor: a practical introduction. Oxford: Oxford University Press.

Kövecses, Z. (2015). Where metaphors come form: reconsidering context in metaphor. Oxford: Oxford University Press.

Lakoff, G. \& Johnson, M. (1980). Metaphors we live by. Chicago: The University of Chicago Press.

Lakoff, G. \& Turner, M. (1989). More than cool reason: a field guide to poetic metaphor. Chicago: The University of Chicago Press.

NTC's thematic dictionary of American idioms. (1997). Spears, R.A. Lincolnwood, IL.: NTC Contemporary Publishing Company.

Obyczaje, języki, ludy świata. (2007). Warszawa: Wydawnictwo Naukowe PWN.

Online etymology dictionary. Available at: http://www.etymonline.com/

Palmatier, R.A. Food: a dictionary of literal and nonliteral terms. (2000). Westport, London: Greenwood Press.

Rawson, H. A dictionary of euphemisms and other doubletalk. (1981). New York: Crown Publishers, Inc. 
Renton, N.E. Metaphorically speaking: a dictionary of 3,800 picturesque idiomatic expressions. (1992). New York: Warner Books, Inc.

St. Peter's Basilica. Available at:

https://en.wikipedia.org/wiki/St._Peter\%27s_Basilica

The book of common prayer. (1999). London: David Campbell Publishers Ltd. 'Introduction' written by MacCulloch, D.

The Longman dictionary of contemporary English. (2012). Harlow: Pearson Education Limited.

Tomb of Pope Alexander VII. Available at:

https://en.wikipedia.org/wiki/Tomb of_Pope_Alexander_VII

Uberman, A. (2006). Modelling the English lexicon in applied linguistics. Rzeszów:

Wydawnictwo Uniwersytetu Rzeszowskiego.

Uberman, A. A semantic frame of DEATH. (forthcoming)

Ungerer, F. \& Schmid, H. (1996) An introduction to cognitive linguistics. London and New York: Longman.

Webber, E. \& Feinsilber, M. Merriam Webster's dictionary of allusions. (1999). Springfield, MA.: Merriam-Webster Inc.

Wierzbicka, A. (2004). Conceptual primes in human languages and their analogues in animal communication and cognition. In Language sciences, 26, p. 413-441.

Wierzbicka, A. (2010). Experience, evidence, and sense: the hidden cultural legacy of English. Oxford: Oxford University Press.

Wierzbicka, A. (2014). Imprisoned in English: the hazards of English as a default language. Oxford: Oxford University Press.

Wierzbicka, A. (1992). Semantics, culture, and cognition. Universal human concepts in culture-specific configurations. New York and Oxford: Oxford University Press. Wierzbicka, A. (1996). Semantics: primes and universals. Oxford: Oxford University Press.

Wilkinson, P.R. Thesaurus of traditional English metaphors. (2002). London and New York: Routledge. 


\section{List of abbreviations}

AHDI - American heritage dictionary of idioms.

$\mathrm{BCP}$ - The book of common prayer.

BDMPF - Brewer's dictionary of modern phrase and fable.

BDPF - Brewer's dictionary of phrase and fable.

DE - How not to say what you mean. A dictionary of euphemisms.

DOED - A dictionary of euphemisms and other doubletalk.

FDLNT - Food: a dictionary of literal and nonliteral terms.

HEI - Harrap's English idioms.

LDCE - The Longman dictionary of contemporary English.

MS - Metaphorically speaking: a dictionary of 3,800 picturesque idiomatic expressions.

MWDA - Merriam Webster's dictionary of allusions.

OJLS - Obyczaje, języki, ludy świata.

TDAI - NTC's thematic dictionary of American idioms

TTEM - Thesaurus of traditional English metaphors.

\section{Notes:}

\footnotetext{
1 "Although the Banshee is a particularly Irish member of the fairy world, when a family she favoured crossed to Britain or emigrated to America she has been known to go with it. She is only interested in old established families and when a member is about to die her lament heralds the event" (Alexander 2006: 13).

${ }^{2}$ They represent virtues practised by the Pope, i.e. Charity, Truth, Prudence, and Justice (St. Peter's Basilica, s.a.).

${ }^{3}$ The underline has been introduced here for emphasis
}

\begin{tabular}{|l|l|}
\hline \multicolumn{2}{|c|}{ Contact data } \\
Agnieszka Uberman, \\
Associate Professor, \\
PhD, Institute of \\
English Studies, \\
University of Rzeszów, \\
al.mjr.W. Kopisto 2B, \\
35-315r Rzeszów, \\
Polandre-mail: \\
ag.uberman@wp.pl
\end{tabular}




\section{Résumé in English}

The present discussion aims to consider the figurative meanings embedded in phrases, expressions, and idioms whose constitutive parts are the selected elements of the semantic frame of DEATH AND DYING. This cognitive construct is a very extensive knowledge structure, therefore only three primary lexemes have been chosen for analysis, namely dead (including also deadly), death, as well as to die. The number of expressions created with those lexical items constitutes a rich source of research material. Prior to analysing the underlying senses of the considered lexical set, the concept of death is introduced with reference to religion, its symbolism and diverse beliefs entrenched in various cultures. The discussion continues with the brief presentation of the semantic and conceptual primes 'life and death' and it is noted that those concepts are composing elements of the orientational as well as conceptual metaphors. Also, frame as a cognitive construct is briefly addressed. The data that have been analysed in the present study have been collected from a number of lexicographic sources. The analytical part is divided into three sections, each of which is devoted to one key lexeme selected for consideration. The discussion allows to arrive at some conclusions, which tend to be of general character. It can be noted that most expressions and phrases created with the use of the analysed elements of the frame of DEATH AND DYING trigger negative connotations and are largely negatively valued. They designate, among other senses, 'failure', 'finality', 'futility of attempt', 'loss of energy', 'lack of appreciation', 'poor condition', 'pain', 'inevitability of the end', 'inability to progress' or 'peril' and 'destruction'. Few examples evidence positive meanings engulfed in linguistic expressions generated in this manner.

Key words: death, symbolism, concept, semantic frame, figurative meaning, metaphor, negative connotation. 


\section{Résumé in German}

Der Beitrag behandelt die übertragene Bedeutung von Wendungen, Ausdrücken und Idiomen, die ausgewählte Elemente des Frames TOD und STERBEN darstellen. Dieses kognitive Modell ist eine sehr umfangreiche Wissensstruktur, so dass nur drei grundlegende lexikalische Einheiten analysiert werden konnten, d. h. tot (zusammen mit sterblich/tödlich), Tod und sterben. Die Anzahl der mit diesen Lexemen gebildeten Ausdrücke stellt ein reiches Untersuchungskorpus dar. Der Analyse des grundlegenden Bedeutungen der besprochenen lexikalischen Menge geht die Darstellung des Begriffs Tod im Hinblick auf die Religion, ihre Symbolik und verschiedene Volksglauben voran, die in einzelnen Kulturen ihren Niederschlag finden. Die weitere Diskussion widmet sich einer kurzen Darstellung von semantischen und konzeptuellen Elementareinheiten 'Leben und Tod', wobei angemerkt wird, dass sie als Bestandteile von Orientierungsmetaphern und konzeptuellen Metaphern fungieren. Darüber hinaus wird auf den semantischen Frame als kognitive Konstruktion kurz eingegangen. Das analysierte Korpus wurde verschiedenen lexikographischen Quellen entnommen. Der analytische Teil setzt sich aus drei Abschnitten zusammen, jeder widmet sich einer grundlegenden lexikalischen Einheit. Die Untersuchung lässt einige allgemeine Schlussfolgerungen zu. Es kann angemerkt werden, dass die meisten Ausdrücke, die mit den analysierten Lexemen im Bereich des Frames TOD und STERBEN gebildet werden, negative Assoziationen hervorrufen und einen negativen Wert haben. Sie bezeichnen u. a. 'Misserfolg', 'Äußerstes', 'Vergebliches', 'Energieverlust', 'Mangel an Anerkennung', 'schwache Kondition', 'Schmerz', 'Unvermeidlichkeit des Endes', 'Unmöglichkeit der Entwicklung', 'Gefahr' oder 'Destruktion'. Lediglich einige Beispiele weisen auf positive Konnotationen der so gebildeten Ausdrücke hin.

Schlüsselwörter: Tod, Symbolismus, Begriff, semantischer Frame, übertragene Bedeutung, Metapher, negative Konnotation. 


\section{Résumé in French}

Le présent article porte sur les significations métaphoriques des tours de parole, locutions et expressions idiomatiques contenant les éléments choisis du cadre sémantique de la MORT. Ce modèle cognitif constitue une structure très large et c'est la raison pour laquelle, pour notre analyse, nous n'avons sélectionné que trois unités lexicales et notamment mort au sens adjectival (y compris la connotation de mortel), la mort et mourir. Le nombre d'expressions créées avec ces lexèmes constitue une riche source pour les chercheurs. L'analyse des sens pléniers du champs lexical en question est précédée d'une présentation de notion de la mort dans le contexte de la religion, de son symbolisme et des différents cultes, ancrés dans les cultures variées. La suite est consacrée à une courte présentation des unités sémantiques et conceptuelles élémentaires telles que 'la vie et la mort'; à noter que celles-ci constituent les composants des métaphores d'orientation et conceptuelles. De surcroît, nous y présentons brièvement la notion de cadre sémantique en tant que construction cognitive. Le matériel analysé au présent article provient de différentes sources lexicographiques. La partie analytique se divise en trois sections dont chacune est dédiée à une unité lexicale de base, choisie pour l'analyse. Les recherches effectuées permettent de formuler certaines conclusions à caractère général. A noter que la majorité des expressions et des locutions contenant les lexèmes analysés, provenant $d u$ cadre sémantique de la MORT évoque des représentations négatives et possède la valeur négative. Elles désignent entre autres 'échec', 'finalité', 'futilité', 'perte d'énergie', 'absence de reconnaissance', 'faible condition', 'douleur', 'caractère inévitable de la fin', 'impossibilité de s'épanouir', voire le 'danger' ou la 'destruction'. Il n'y a que quelques exemples qui contiennent des connotations positives des locutions créées à partir de ces notions.

Mots-clés: mort, symbolisme, notion, cadre sémantique, sens figuré, métaphore, connotation négative. 


\section{Résumé in Russian}

Настоящее исследование посвящено рассмотрению переносных значений, закрепленных в фразах, выражениях и идиомах составные части которых являются отдельными элементами семантического фрейма СМЕРТЬ И УМИРАНИЕ. Эта когнитивная конструкция является очень обширной структурой знаний, поэтому только три первичные лексемы были выбраны для анализа, а именно dead (deadly включительно), death, а также to die. Количество выражений, созданных с помощью этих лексических единиц, представляет собой богатый источник исследовательского материала. До начала анализа глубинных значений рассматриваемой лексической группы, понятие смерти оговаривается в контексте религии, её символики и разнообразных верований, представленных в различных культурах. Дальше кратко обсуждаются семантические и концептуальные примитивы 'жизнь и смерть' и отмечается, что эти концепты являются составляющими элементами ориентационных и концептуальных метафор. Кроме того, кратко рассматривается фрейм как когнитивный конструкт. Данные были собраны из ряда лексикографических источников. Аналитическая часть разделена на три секции, каждая из которых посвящена одной из ключевых лексем, выбранной для рассмотрения. Обсуждение приводит к некоторым обобщениям. Выражения и фразы, созданные с помощью элементов фрейма DEATH AND DYING, имеют отрицательные коннотации и в значительной степени негативно окрашены. Они обозначают, среди прочих значений, 'провал', 'окончательность', 'тщетность попыток', 'потерю энергии', 'недооценку', 'плохое состояние', 'боль', 'неизбежность конца', 'неспособность к прогрессу', либо 'опасность' и 'уничтожение'. Некоторые примеры производных языковых выражений имеют положительные значения.

Ключевые слова: смерть, символика, концепт, семантический фрейм, переносное значение, метафора, негативная коннотация. 
Article was received by the editorial board 30.11.16;

Reviewed 4.12.16 and 11.12.16.

Similarity Index 19\%. 